\title{
Aktualisasi Diri Generasi Milenial Melalui Aplikasi TikTok
}

\author{
Putri Micella Pellondou, Farid Rusdi \\ putrimichellap@gmail.com,farid@fikom.untar.ac.id
}

Fakultas Ilmu Komunikasi Universitas Tarumanagara

\begin{abstract}
Self-actualization is a person's desire to use all of his abilities to achieve whatever they want and can be done by developing the potential that exists within an individual. Selfactualization of an individual can be formed from the surrounding environment and various kinds of increasingly advanced technological developments. In this digital era, it is encouraging millennials to use social media as a platform to actualize themselves and one of them is Tiktok. Tiktok Tiktok is a social media that accompanies videos or images with various types of music. The research method used in this research is qualitative with data collection techniques in the form of interviews and documentation. The results of the study indicate that the use of one's social media in building the expected self-image in social media uses the Dramaturgy theory of American sociologist Erving Goffman.
\end{abstract}

Keywords: millennial, self-actualization, social media, tiktok

\begin{abstract}
Abstrak
Aktualisasi diri adalah keinginan seseorang untuk menggunakan semua kemampuan dirinya untuk mencapai apapun yang mereka mau dan bisa dilakukan dengan mengembangkan potensi yang ada di dalam diri seorang individu. Aktualisasi diri seorang individu dapat terbentuk dari lingkungan sekitar dan berbagai macam perkembangan teknologi yang semakin maju. Di jaman yang sudah serba digital ini mendorong generasi millenial dalam menggunakan media sosial sebagai platform untuk mengaktualisasi diri mereka dan salah satunya adalah Tiktok. Tiktok merupakan media sosial yang mengiringi video atau gambar dengan berbagai jenis musik. Metode penelitian yang digunakan dalam penelitian ini adalah kualitatif dengan teknik pengumpulan data berupa wawancara dan dokumentasi. Hasil dari penelitian menunjukkan bahwa penggunaan sosial media seseorang dalam membangun citra diri yang diharapkan dalam media sosial dengan menggunakan Teori Dramaturgi dari sosiolog Amerika, Erving Goffman.
\end{abstract}

Kata Kunci: aktualisasi diri, media sosial, milenial, tiktok

\section{Pendahuluan}

Aplikasi Tiktok merupakan media sosial yang mengiringi video atau gambar dengan berbagai jenis musik. Tiktok berasal dari Tiongkok pada September 2016 oleh Zhang Yiming, yang juga pendiri Toutiao. Fitur-fitur Tiktok sangat menarik sehingga menjadi daya tarik sendiri. Tiktok menyediakan fitur musik, sehingga saat pengambilan video terdapat backsound, fitur effect yang akan mendektesi wajah dan meletakkan effect sesuai dan tepat pada wajah. Lalu fitur merubah suara asli menjadi suara orang lain atau disebut dengan lip sync. Dalam beberapa waktu ini, media sosial Tiktok menjadi viral di kalangan milenial ditunjukkan dengan penggunaan yang meningkat.

Generasi milenial menggunakan berbagai platform media sosial untuk mengaplikasikan aktualisasi diri seperti melalui Facebook, Twitter, dan lain-lain. 
Pada penelitian ini hanya akan membahas platform Tiktok, karena saat masa pandemi ini generasi milenial banyak membuat video melalui aplikasi Tiktok. Tidak heran aplikasi Tiktok menjadi aplikasi terpopuler nomor 2 di Google Playstore. Tiktok menjadi aplikasi yang digemari milenial karena memilki fitur-fitur yang unik. Tiktok menyaingi media sosial Instagram. Video Tiktok dapat dibagikan melalui platform lainya seperti Line, Twitter, dan Instagram. Keunikan Tiktok adalah dapat dimainkan bersama dengan teman dan keluarga, Tiktok dinilai menghibur, saat kumpul bersama teman atau keluarga dapat bersama-sama membuat video di Tiktok. Tiktok tepat untuk pengguna yang suka menari (dance) karena menyediakan backsound saat pengguna melakukan gerakan. Pada aplikasi Tiktok saat menggunakanya akan menemui berbagai macam konten seperti, dance, lip sync, konten tutorial, dan lainya. Tiktok dinilai menghibur, karena tidak monoton, dan tidak membosankan.

Menurut Teori Hierarki Kebutuhan Maslow (Robbins, 2003:126), terdapat lima kebutuhan yang dimilki oleh manusia, pertama kebutuhan dasar yaitu kebutuhan fisiologis, kebutuhan keamanan, kebutuhan sosial dan penghargaan, serta kebutuhan tingkat tertinggi yaitu aktualisasi diri. Aktualisasi merupakan semua bakat yang dimiliki digunakan atau show off, pemenuhan semua kualitas dan kapasitas dalam diri seorang individu. Saat pengguna Tiktok melakukan sebuah konten, akan menggunakan aktualisasi yang ada pada dalam diri, dan lebih ekstra dan lebih dalam konten itu. Aktualisasi diri mendorong mental seseorang lebih yakin dan lebih merasa menguasai audience. Aktualisasi diri memberikan energi positif, sehingga saat melakukan sesuatu hal, lalu dikritik dan diberi masukan tidak menjadikan itu tekanan mental.

Menurut Maslow aktualisasi diri adalah cara menjadi diri sendiri dan menggembangkan potensi yang ada dalam diri seorang individu. Aktualisasi diri akan berkembang dan akan terjadi perubahan dalam diri seorang individu seiring berkembang nya seorang individu (Arianto, 2009). Seorang individu akan cenderung ingin dicintai, serta disukai oleh orang lain. Tujuan seorang individu mengaktualisasikan diri di media sosial adalah untuk mendapatkan perhatian, lalu ingin mendapatkan like yang banyak. Aktualisasi diri termotivasi dari lingkungan sekitar, dengan adanya perubahan perkembangan teknologi yang terjadi, sehingga menggiring milenial. Aktualisasi diri bisa terjadi bila milenial dapat mengatahui potensi apa saja yang ada dalam diri nya, sehingga dapat memahami kemampuanya.

Pengguna yang mengaktualisasikan diri di Tiktok terkadang menggunakan topeng untuk membentuk citra dirinya di depan audience. Milenial menjadi pemeran di mana waktu berinteraksi dan lokasi terjadinya adalah panggung sandiwara antara pemain peran dan audience. Contohnya si A adalah pengguna Tiktok yang memiliki banyak pengikut (followers) karena konten sangat digemari oleh audiencenya, A menggunakan Tiktok sebagai panggung sandiwara untuk melakukan peran sandiwaranya. Tetapi ternyata pada kehidupan nyata, A adalah seorang yang tidak lucu dan terkadang pendiam, sangat berbanding terbalik dengan peran yang ditunjukkan di Tiktok.

Contoh lainnya seorang individu akan bertemu dengan orang yang baru dan belum dikenal, saat akan menemui orang baru dan belum dikenal itu, individu akan mempersiapkan topengnya, seperti tutur bahasa, gaya bicara, bahasa tubuh, dan lainlain. Tujuanya agar membangun citra yang baik kepada orang yang akan ditemui dan belum dikenal. Tetapi setelah bertemu dengan orang baru dan belum dikenal tersebut, saat individu kembali ke ke kehidupan nyata, individu akan menggunakan 
topeng aslinya, tanpa perlu memikirkan membangun citra yang baik kepada keluarga maupun sahabatnya.

\section{Metode Penelitian}

Pendekatan yang digunakan dalam penelitian ini adalah penelitian kualitatif. Pendekatan kualitatif mempunyai karakter alami sebagai sumber data secara langsung, deskriptif, hasil tidak terlalu dipentingkan, tetapi proses lebih dipentingkan. Analisis penelitian kualitatif cenderung dilakukan secara analisis induktif dan makna makna merupakan hal yang esensial (Moleong, 2006). Metode penelitian yang digunakan adalah penelitian deskriptif kualitatif dengan metode analitis. Metode deskriptif dipilih karena penelitian yang dilakukan adalah berkaitan dengan peristiwa-peristiwa yang sedang berlangsung dan berkenaan dengan kondisi masa sekarang. Nazir (2011) menjelaskan bahwa metode deskriptif adalah satu metode dalam meneliti status kelompok manusia, suatu subjek, suatu set kondisi, suatu sistem pemikiran atau pun kelas peristiwa pada masa sekarang. Tujuan dari penelitian deskriptif ini adalah membuat deskripsi, gambaran atau lukisan secara sistematis serta hubungan antar fenomena yang diselidiki.

Subyek dalam penelitian ini adalah anak muda atau millenial yang menggunakan Tiktok untuk mengaktualisasikan diri mereka. Kriteria narasumber adalah pengguna aplikasi Tiktok dan membuat konten Tiktok dan merupakan anak Milenial, 4 orang yang akan menjadi narasumber adalah anak muda yang membuat konten di Tiktok. Objek di dalam penelitian kualitatif ini adalah aktualisasi diri generasi milenial di aplikasi Tiktok. Metode pengumpulan data menggunakan wawancara tak berstruktur atau metode wawancara langsung dengan subjek informan. Peneliti menggunakan wawancara tak terstruktur yaitu wawancara yang bentuk pertanyaannya bebas (pertanyaan langsung tanpa daftar yang telah disusun sebelumnya). Selain itu peneliti juga menggunakan observasi dan dokumentasi sebagai alat pendukung.

Teknik pengelohan data yang dilakukan dalam penelitian ini adalah dengan menguraikan data dalam bentuk kalimat teratur, runtun, logis, tidak tumpeng tindih, dan efektif sehingga memudahkan pemahaman dan interpretasi data. Diantaranya melalui tahap; pemeriksaan data (editing), klasifikasi (classifying), verifikasi (verifying), analisis (analysing), dan pembuatan kesimpulan (concluding).

\section{Hasil Temuan dan Diskusi}

Dari data penelitian yang sudah didapatkan melalui wawancara antara peneliti dengan empat narasumber yang aktif menggunakan aplikasi Tiktok dan membuat konten Tiktok. Pertama subjek Philip menggunakan aplikasi Tiktok untuk mengedukasi dan menghibur penonton (viewers). Konten yang dibuat oleh subyek Philip untuk menyalurkan hobi. Subjek Philip juga menyadari bahwa tren Tiktok ini sedang berkembang, dengan kreatifitas ia dapat mengembangkan ide dengan membuat video di Tiktok. Konten yang ia buat adalah merekomendasikan kafe-kafe dan tempat minum kopi di Jakarta yang belum diketahui oleh banyak orang.

Subjek Philip juga menggunakan Tiktok untuk berkarya, karena subjek Philip adalah orang yang menyukai videography. Dengan adanya Tiktok, subjek Philip dapat menyalurkan kelebihanya dan kreatifitas saat membuat video di platform Tiktok ini. Philip juga mengatakan bahwa Tiktok dijadikan sebagai platform untuk 
mengaktualisasikan diri dan juga hobi. Saat itu Philip mengikuti tren dan Philip menyadari bahwa Tiktok berguna untuk menuangkan kepercayaan diri dengan berkreativitas. Hal-hal yang ingin disampaikan dalam pesan di kontennya adalah untuk mengedukasi. Subyek Philip memiliki harapan agar dari kreatifitas muncul hal-hal positif, serta tanggapan penonton yang positif terhadap konten yang telah dibuat. Philip mengharapkan dapat mengubah pola pikir penonton agar tidak menggunakan Tiktok hanya sebagai tempat untuk mencari hiburan dan membuat hoax. Philip berharap penonton menggunakan Tiktok sebagai tempat untuk belajar, dan mengharapkan para content creator menggunakan Tiktok sebagai tempat untuk mengedukasi audiens.

Kedua, subjek Ivonne menggunakan aplikasi di Tiktok menyadari bahwa ia sangat menyukai Tiktok, eksistensi yang ia ingin dapatkan menjadikan hal yang mendorong untuk ingin memainkan Tiktok, serta aktif membuat konten. Ide-ide yang ia dapatkan pun teinspirasi dari sesama pengguna di Tiktok. Ivonne mengikuti gaya dan tren di Tiktok agar eksistensinya tercapai. Berawal dari iseng-iseng mengikuti perkembangan zaman dan menyukai fitur-fitur Tiktok yang cocok dengan kepribadiannya, Ivonne memainkan Tiktok untuk berkreasi menyalurkan kepercayaan diri dan menghibur penonton. Dalam arti terdapat upaya win-win solution di mana ia menyalurkan hobi dan kepercayaan diri dalam konten Tiktok, sementara penonton terhibur dengan konten yang telah ia buat. Menurut Ivonne ada perbedaan di kehidupan nyata dan di Tiktok. Walaupun di Tiktok ia menyatakan tidak membuat drama, tetapi melalui Tiktok ia hanya menjadi Ivonne yang ceria dan menyenangkan.

Saat di kehidupan nyata Ivonne adalah seorang manusia yang kehidupanya tidak hanya mengenai kesenangan saja, tetapi juga pernah mengalami kesedihan. Dalam hal ini sesuai teori dramaturgi, Ivonne adalah seorang yang membagi penampilannya di panggung menjadi dua, saat ia membuat konten di Tiktok ia harus menggunakan topeng di mana ia merasa gembira. Penonton hanya mengetahui Ivonne adalah seseorang yang sesuai dengan topeng yang ia kenakan saat membuat konten. Penonton Ivonne akan menilai Ivonne adalah seorang yang menyenangkan, seorang yang tidak suka drama. Tetapi saat di kehidupan nyata Ivonne menggunakan topeng lain yang ditunjukan kepada orang terdekat saja. Di kehidupan Ivonne tidak hanya diisi dengan kegembiraan dan kesenangan, Ivonne adalah manusia biasa dengan kehidupan emosional yang beragam.

Ketiga, subjek Gerry aktif di Tiktok karena ingin mengekspresikan diri melalui konten-konten yang dibuat. Ia juga ingin menginspirasi penontonnya. Gerry juga mengekspresikan diri melalui konten fashion. Konten yang dibuat adalah Korean Street Style. Gerry menginginkan agar penonton lebih teredukasi mengenai fashion, terutama Korean fashion. Gerry menginformasikan mix and match, bagaimana pakaian bagian atas dan bawah cocok dipadukan. Gerry juga ingin dilihat dan diingat oleh penontonnya, seperti saat penontonnya berbelanja di suatu toko, saat melihat baju ini, mereka ingat bahwa "wah ini gaya Gerry Hadi banget ya".

Gerry tidak mempermasalahkan tanggapan penonton tetapi berharap tanggapan dalam bentuk komentar tersebut positif. Gerry juga tetap akan melakukan apa yang senang dilakukan tanpa memedulikan apa kata orang. Gerry juga mengedukasikan bagaiman cara berpose, agar tidak kaku, selayaknya model dan lebih terlihat keren. Melalui Tiktok, Gerry tidak mengharapkan semua orang mengikuti gayanya. Ia hanya ingin dijadikan sebagai salah satu referensi agar penonton mengerti gaya pakaian Korea yang menarik. Ia melihat banyak pertanyaan 
bagaimana berpose yang baik, bagaimana agar tidak terlihat kaku dan natural. Menurut Gerry konten-konten di Tiktok dan Instagram berbeda. Media sosial Instagram hanya berisi foto-foto dan foto kisah (stories), tetapi dalam platform Tiktok, pengguna bisa mengekspresikan diri lebih jauh. Tiktok bisa menciptakan konten video lucu, sedih, dan lain lain. Menurut Gerry, konten di Tiktok dapat dibagikan juga di Instagram. Gerry merasa mendapat dukungan di Instagram dan di Tiktok, ditunjukkan dengan komentar positif dan banyaknya pengguna yang menyukai.

Terakhir, subjek Eci berawal dari iseng mengikuti tren bermain Tiktok untuk mengikuti jaman. Eci menggunakan Tiktok untuk menyalurkan hobi dan passion yaitu menari (dance) dan menyanyi. Oleh karena itu, konten yang dibuat oleh Eci adalah dance dan bernyanyi. Saat membuat konten, Eci berharap agar konten yang dibuat menginspirasi penonton. Manfaat yang ingin diberikan adalah untuk menghibur karena konten yang dibuat adalah konten bernyanyi, dan dance. Ide yang muncul untuk konten Eci berasal dari video-video pembuat konten di Tiktok lainya, lalu di-remake. Eci memainkan Tiktok berawal dari ramainya pengguna dan banyak yang mengunggah di Instagram. Eci beranggapan orang yang membuat konten di Tiktok adalah orang yang kreatif karena membuat konten itu tidak mudah. Menurut Eci semua orang yang menggunakan media sosial tidak pernah menunjukkan diri dia yang sebenarnya kepada penontonnya. Menurutnya tidak ada yang akan menunjukan apa yang sebenarnya dirasakan, karena semua orang ingin membangun citra (image) tentang diri mereka sendiri. Untuk membangun citra diri itu orang tidak akan menunjukkan diri mereka yang sebenarnya.

Dalam analisis ini, penulis mewawancarai empat orang anak muda dalam kategori generasi milenial yang menggunakan aplikasi Tiktok. Generasi milenial tidak dapat dipisahkan dengan teknologi, apalagi media sosial. Tiktok dianggap memiliki keunikan dan menjadi pilihan generasi milenial untuk menyalurkan bakat. Dengan fitur Tiktok yang lebih canggih membuat generasi milenial semakin menyukai aplikasi ini. Dalam Tiktok banyak sekali fitur-fitur yang tidak dimiliki aplikasi lain. Tiktok juga memudahkan pengguna yang ingin membagikan video melalui Instagram atau media sosial lainya.

\section{Simpulan}

Penelitian ini menunjukkan bahwa media sosial digunakan untuk membangun citra diri yang diharapkan. Dengan menggunakan teori dramaturgi dari sosiolog Amerika Serikat, Erving Goffman, terlihat bahwa terdapat perbedaan antara pengguna media sosial di dalam kehidupan dunia maya dan dunia nyata. Pengguna media sosial Tiktok terlihat seperti memiliki kepribadian ganda.

\section{Ucapan Terima Kasih}

Ucapan terima kasih peneliti sampaikan kepada narasumber yang sudah membantu memberikan informasi terkait dengan penelitian, serta Fakultas Ilmu Komunikasi Universitas Tarumanagara yang telah mendukung seluruh proses penelitian. 


\section{Daftar Pustaka}

Amirullah, N. (2017). Penggunaan Instagram Sebagai Media Aktualisasi Diri Komunitas Miniatur Figur Indonesia di Balikpapan.

Kholisotin, U. (2015). Penikahan Dini Di Dusun Palu Desa Karang Pinang Kecamatan Kembang Kabupaten Bojonegoro: Tinjauan Dramaturgi (Doctoral dissertation, UIN Sunan Ampel Surabaya).

Kurniawan, I. (2018). Gambaran Aktualisasi Diri Penyandang Disabilitas Di Yogyakarta (Doctoral dissertation, Universitas Mercu Buana Yogyakarta).

Maemona, R., \& Pratiwi, M. R. (2020). TEKNIK ASOSIASI: STRATEGI PESAN DAKWAH DI INSTRAGRAM. Jurnal Riset Komunikasi, 3(2), 254-268.

Mamari, R. L. P. (2017). Studi Perencanaan Perkerasan Lentur Jalan Raya Dengan Standar Bina Marga Pada Ruas Jalan Sentani-Warumbain KM 41+ 000-KM $61+000(20 \mathrm{KM})$ (Doctoral dissertation, ITN MALANG).Rahayu, D. P. (2015). Persepsi Masyarakat Terhadap Etika Komunikasi Pembawa Acara Berita Tepian TV Dalam Memberikan Pesan Berita Kepada Masyarakat Seputar Kota Samarinda. e Journal Komunikasi, 3(3).

Melati, M. (2015). Analisis Konsep Dramaturgi Erving Goffman Dalam Pola Penggunaan Ruang Publik Kafe Oleh Mahasiswa di Kota Surakarta. Sosialitas: Jurnal Ilmiah Pendidikan Sosiologi-Antropologi, 5(2), 163552. 